\title{
New records of lichens and lichenicolous fungi from Dagestan, Russia
}

\author{
Gennadii Urbanavichus ${ }^{1} \&$ Aziz Ismailov ${ }^{2}$ \\ ${ }^{1}$ Institute of the North Industrial Ecology Problems, Kola Science Centre, Russian Academy of Sciences, \\ Akademgorodok 14 a, Apatity, 184209, Murmansk region, Russia. E-mail: g.urban@mail.ru \\ ${ }^{2}$ Mountain Botanical Garden, Dagestan Science Centre, Russian Academy of Sciences, M. Gadjieva St. 45, \\ Makhachkala, 367000, Republic of Dagestan, Russia. E-mail: i.aziz@mail.ru
}

\begin{abstract}
Twenty-three species of lichens and five lichenicolous fungi are reported for the first time for Dagestan. Of them, Bellemerella polysporinae, Lecanora pannonica, Opegrapha lutulenta, Porpidinia tumidula and Verrucaria praerupta are new to Caucasus and Russia; Lecanora contractula, Strangospora deplanata and Tremella candelariellae are reported for the first time from Caucasus. Opegrapha lutulenta and Tremella candelariellae are new to Asia. The genera Bellemerella, Didymocyrtis, Leprocaulon, Porpidinia, Protoparmelia, Strangospora and Tremella are reported for the first time from Dagestan. Porpidinia and Bellemerella are genera new to Russia. The most noteworthy records are briefly discussed.
\end{abstract}

Keywords: distribution, lichen diversity, biogeography, Northern Caucasus.

\section{INTRODUCTION}

In contrast to the relatively well-studied lichen flora of the western part of the Russian Caucasus, its eastern part (including southern Dagestan) still remains poorly explored. Lichen flora of Dagestan stayed unexplored for a long time: about sixty lichen species are only included in the Dagestanian lichen flora (Barkhalov, 1983), the last publication before our investigations. Recent lichenological research in Dagestan started in 2009 and soon forty additional species were reported from the Dagestan State Nature Reserve (Urbanavichus et al., 2010). About fifty further species were recorded from Ersi beech forest (Ismailov \& Urbanavichus, 2013). The most extensive publication reports 446 species of lichens and lichenicolous fungi from the Gunib Plateau, Inner Mountain Dagestan (Urbanavichus \& Ismailov, 2013). But none of the recent studies has provided any information on lichen species of coastal lowlands, the target area of our present paper. Our list includes 28 species of lichens and lichenicolous fungi new to Dagestan; these increase the number of species known from Dagestan to about 600 which is approximately $40 \%$ of species known in whole Northern Caucasus. Most of the reported species are widely distributed, usually with distribution centres in arid to semi-arid regions, however, such species have been only rarely recorded from the Caucasian region.

\section{STUDY AREA}

The Republic of Dagestan is located at the boundary between Europe and Asia, in the eastern part of the Northern Caucasus, and is the southernmost region of Russia (Fig. 1). Bordering areas are: internally - Kalmyk Republic (N), Chechen Republic (W), and Stavropol territory (NW); internationally - Azerbaijan (S), and Georgia (SW). Area of the Republic is 50,300 square kilometres. Its southern part is mountainous covered by the Greater Caucasus Mountains (highest Bazardyuzi peak at 4466

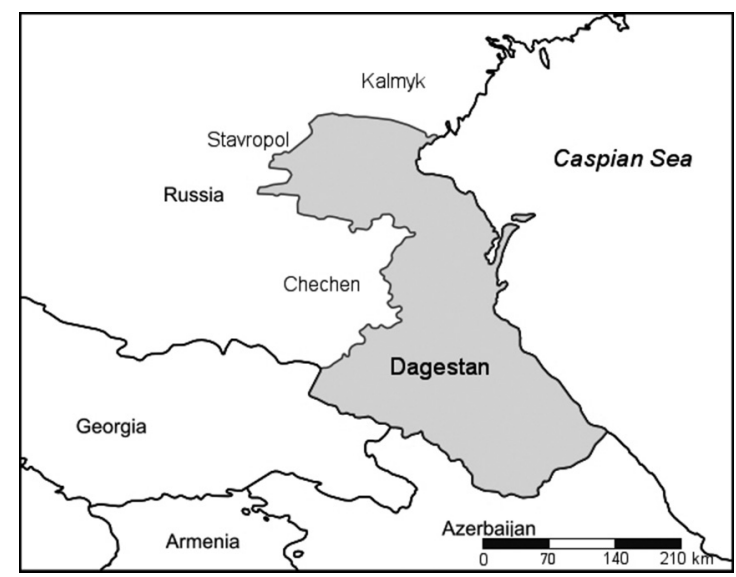

Fig. 1. Location of the study area (Republic of Dagestan). 
$\mathrm{m})$, the northern part is flat with semidesert vegetation. Our studies were focused to the narrow belt of coastal lowlands between the mountains and the Caspian Sea, 3-20 km wide. These coastal lowlands are covered by marine sediments with degraded steppe vegetation. The climate is generally temperate continental and arid. The mean annual temperature on the coast is $12.7^{\circ} \mathrm{C}$, ranging from $1.2^{\circ} \mathrm{C}$ in January to $25^{\circ} \mathrm{C}$ in August. The mean annual precipitation on the coast is c. $350-400 \mathrm{~mm}$ (Gadjieva \& Solovyov, 1996).

\section{MATERIAL AND METHODS}

Records for the present paper were collected by the authors during a short field work in coastal lowlands of Dagestan in July 2015 (with an exception of one Strangospora which was collected by A. Ismailov in 2013). The geographical coordinates were measured with hand-held GPS navigator. Most of species were identified using a stereomicroscope or compound microscope, and the usual spot tests with standard identification methods for lichenized and lichenicolous fungi. The specimens are kept in the herbarium of the Mountain Botanical Garden, Dagestan Scientific Centre, Makhachkala (DAG), and in the private herbarium of G. Urbanavichus. The taxa are listed in alphabetical order, followed by locality with Dagestanian administrative district, coordinates, substrate type, date of collection and collectors. Collectors are abbreviated as AI - Aziz Ismailov, GU - Gennadii Urbanavichus. Genera new to Dagestan are marked with \#.

\section{LIST OF SPECIES}

ACAROSPORA PELISCYPHA Th. Fr. - Karabudakhkent district, $\mathrm{N}$ of Taulargol village, $42^{\circ} 50^{\prime} 13^{\prime \prime} \mathrm{N}$, $47^{\circ} 34^{\prime} 58.5$ " $\mathrm{E}$, on sandstone, 24.07.2015, leg. AI. New to Northern Caucasus. In Transcaucasia, the species was previously recorded from Azerbaijan (Barkhalov, 1983).

Acarospora versicolor Bagl. \& Carestia Karabudakhkent district, $\mathrm{S}$ of Taulargol village, $42^{\circ} 49^{\prime} 36.5^{\prime} \mathrm{N}, 4^{\circ} 35^{\prime} 05.6$ " $\mathrm{E}$, on sandstone, 24.07.2015, leg. GU. New to Northern Caucasus. In Transcaucasia, this species has been recently reported from Armenia (Gasparyan et al., 2015).

AlyXoria CUlmigena (Libert) Ertz - Karabudakhkent district, $2.5 \mathrm{~km} \mathrm{~S}$ of Malyj Uitash village, $42^{\circ} 47^{\prime} 19.4$ "N, 47³5'20"E, on Quercus petraea, 24.07.2015, leg. GU. In Caucasus, the species was previously reported only from the Krasnodar Area (Himelbrant et al., 2003).

ARTHONIA VARIANs (Davies) Nyl. - Karabudakhkent district, $2.5 \mathrm{~km} \mathrm{~S}$ of Malyj Uitash village, $42^{\circ} 47^{\prime} 19.4$ "N , 47 35'20" $\mathrm{E}$, lichenicolous fungus on apothecia of Lecanora rupicola on sandstone, 24.07.2015, leg. GU. In Caucasus, the species was previously reported from the Republic of Northern Ossetia (Vainio, 1899) and the Abrau Peninsula, Krasnodar Area (Urbanavichus \& Urbanavichene, 2015a).

\#Bellemerella Polysporinae Calat. \& Nav.-Ros. Karabudakhkent district, $\mathrm{N}$ of Taulargol village, $42^{\circ} 50^{\prime} 13$ ” N, 47³4'58.5” $\mathrm{E}$, lichenicolous fungus on apothecia and thallus of Polysporina subfuscescens on sandstone, 24.07.2015, leg. GU. New to Russia, Caucasus and Asia. This species was known only from the type locality in Spain growing on Polysporina simplex (Calatayud \& Navarro-Rosinés, 2001). The Dagestanian specimen agrees well with the original description. This is the first report of the genus for Russia and Caucasus.

\#Didymocyrtis Ramalinae (Roberge ex Desm.) Ertz, Diederich \& Hafellner - Karabudakhkent district, Malyj Uitash village, $42^{\circ} 48^{\prime} 34.1^{\prime \prime} \mathrm{N}$, $47^{\circ} 35^{\prime} 49.9^{\prime \prime} \mathrm{E}$, lichenicolous fungus on thallus of Ramalina capitata on sandstone, 24.07.2015, leg. GU. In Russia and Caucasus, this species has been recently reported by Urbanavichus and Urbanavichene (2015b) from the Abrau Peninsula, Krasnodar Area (as Leptosphaeria ramalinae (Desm.) Sacc.).

Diplotomma CHLOROPHAEum (Hepp ex Leight.) Szatala - Karabudakhkent district, $\mathrm{N}$ of Taulargol village, $42^{\circ} 50^{\prime} 13^{\prime \prime} \mathrm{N}, 47^{\circ} 34^{\prime} 58.5^{\prime \prime} \mathrm{E}$, on sandstone, 24.07.2015, leg. AI \& GU. Ibid., S of Taulargol village, $42^{\circ} 49^{\prime} 36.5^{\prime} \mathrm{N}, 47^{\circ} 35^{\prime} 05.6^{\prime \prime} \mathrm{E}$, on sandstone, 24.07.2015, leg. GU. In Northern Caucasus, this species has been recently reported by Urbanavichus and Urbanavichene (2015a) from the Abrau Peninsula, Krasnodar Area. In Transcaucasia, the species was recorded from Armenia, Azerbaijan and Georgia (Barkhalov, 1983).

Gyalecta Carneola (Ach.) Hellb. - Karabudakhkent district, $2.5 \mathrm{~km} \mathrm{~S}$ of Malyj Uitash village, $42^{\circ} 47^{\prime} 19.4$ "N, $47^{\circ} 35^{\prime} 20^{\prime} \mathrm{E}$, on Quercus petraea, 24.07.2015, leg. GU. In Caucasus, this species 
was only recorded from the Krasnodar Area (Himelbrant \& Kuznetsova, 2002).

INTRALICHEN LICHENICOLA (M. S. Christ. \& D. Hawksw.) D. Hawksw. \& M. S. Cole - Karabudakhkent district, Malyj Uitash village, 42 48'34.1”N, $47^{\circ} 35^{\prime} 49.9$ " $\mathrm{E}$, lichenicolous fungus on apothecia of Candelariella vitellina on sandstone, 24.07.2015, leg. GU. In Caucasus, this species has been recently reported from the Republic of Adygea and Krasnodar Area (Urbanavichus \& Urbanavichene, 2014).

LeCANIA tURICEnsis (Hepp) Müll. Arg. - Karabudakhkent district, the Caspian Sea shore, ca. $1.5 \mathrm{~km}$ S of sanatorium "Chajka", 42 $41^{\circ} 08.7$ " N, 47 43'37.4” $\mathrm{E}$, on calcareous rocks, 25.07.2015, leg. GU. In Caucasus, this species was only recorded from the Republic of Adygea (Urbanavichus \& Urbanavichene, 2014), Armenia and Azerbaijan (Barkhalov, 1983).

LECANORA CENISIA Ach. - Karabudakhkent district, S of Taulargol village, $42^{\circ} 49^{\prime} 36.5^{\prime \prime} \mathrm{N}$, $47^{\circ} 35^{\prime} 05.6$ " E, on sandstone, 24.07.2015, leg. GU. The species is widely distribution in Caucasus: Krasnodar Area (Krivorotov, 1997), Republics of Kabardino-Balkaria (Slonov, 2002) and Karachaevo-Cherkessia (Blinkova \& Urbanavichus, 2005), Stavropol Area, Abkhasia, Azerbaijan and Georgia (Barkhalov, 1983).

LECANORA CONTRACTULA Nyl. - Karabudakhkent district, $\mathrm{S}$ of Taulargol village, $42^{\circ} 49^{\prime} 36.5^{\prime \prime} \mathrm{N}$, $47^{\circ} 35^{\prime} 05.6$ " $\mathrm{E}$, on sandstone, 24.07.2015, leg. GU. New to Caucasus.

LECANORA GANGALEOIDES Nyl. - Karabudakhkent district, $\mathrm{N}$ of Taulargol village, $42^{\circ} 50^{\prime} 13^{\prime \prime} \mathrm{N}$, $47^{\circ} 34^{\prime} 58.5^{\prime} \mathrm{E}$, on sandstone, 24.07.2015, leg. AI. In Caucasus, this species has been reported from the Abrau Peninsula, Krasnodar Area (Otte, 2005) and Azerbaijan (Barkhalov, 1983).

LECANORA PANNONICA Szatala - Karabudakhkent district, $\mathrm{N}$ of Taulargol village, $42^{\circ} 50^{\prime} 13^{\prime \prime} \mathrm{N}$, $47^{\circ} 34^{\prime} 58.5$ " $\mathrm{E}$, on sandstone, 24.07.2015, leg. GU. Ibid., S of Taulargol village, $42^{\circ} 49^{\prime} 36.5^{\prime \prime} \mathrm{N}$, $47^{\circ} 35^{\prime} 05.6$ " $\mathrm{E}$, on sandstone, 24.07.2015, leg. GU. New to Russia and Caucasus. The species is known from many regions of Western Europe and southwestern North America (Ryan et al., 2004). L. pannonica may be similar to the sorediate Tephromela grumosa. However, the latter species is readily distinguished by a different chemistry (contains lichesterinic acid as major compound, with traces of atranorin), and it has coalescing soralia.

\#LEPROCAULON QUiSQUiliare (Leers) M. Choisy (Leprocaulon microscopicum (Vill.) Gams) Karabudakhkent district, $\mathrm{N}$ of Taulargol village, $42^{\circ} 50^{\prime} 13$ " N, 47 $34^{\prime} 58.5^{\prime} \mathrm{E}$, among mosses at the base of dry, rather unstable, sandy cliffs, 24.07.2015, leg. AI \& GU. In Northern Caucasus, this species has been recently reported by Urbanavichus and Urbanavichene (2015a) from the Abrau Peninsula, Krasnodar Area. Formerly known from Georgia and Azerbaijan (Barkhalov, 1983) and recently reported from Armenia (Gasparyan et al., 2015).

Opegrapha Lutulenta Nyl. - Karabudakhkent district, $2.5 \mathrm{~km} \mathrm{~S}$ of Malyj Uitash village, $42^{\circ} 47^{\prime} 19.4$ " $\mathrm{N}, 47^{\circ} 35^{\prime} 20^{\prime \prime} \mathrm{E}$, on steeply inclined, basic sandstone, 24.07.2015, leg. GU. New to Russia, Caucasus and Asia. The species was formerly known from Mediterranean and Macaronesia (Egea \& Rowe, 1987; Hafellner, 1995).

Physconia PETRAEA (Poelt) Vězda \& Poelt - Karabudakhkent district, $2.5 \mathrm{~km}$ S of Malyj Uitash village, $42^{\circ} 47^{\prime} 19.4^{\prime \prime} \mathrm{N}, 47^{\circ} 35^{\prime} 20^{\prime \prime} \mathrm{E}$, over the moss on sandstone, 24.07.2015, leg. GU. In Russia and Caucasus, this species has only been recorded from the Republic of Northern Ossetia (Otte et al., 2002).

Placopyrenium bucekil (Nádv. \& Servít) Breuss - Karabudakhkent district, S of Taulargol village, $42^{\circ} 49^{\prime} 36.5^{\prime} \mathrm{N}, 47^{\circ} 35^{\prime} 05.6^{\prime} \mathrm{E}$, on sandstone (specimen was infected by Muellerella pygmaea (Körb.) D. Hawksw.), 24.07.2015, leg. GU. Derbent district, limestone cliffs on the right bank of the Rubas river, $41^{\circ} 52^{\prime} 16.4^{\prime \prime} \mathrm{N}, 48^{\circ} 17^{\prime} 02.9^{\prime \prime} \mathrm{E}$, on calcareous rocks, 17.07.2015, leg. GU. This species has been reported from the Republic of Northern Ossetia and Armenia (Breuss, 2009).

\#Porpidinia tumidula (Sm.) Timdal - Derbent district, limestone cliffs on the right bank of the Rubas river, $41^{\circ} 52^{\prime} 16.4^{\prime \prime} \mathrm{N}, 48^{\circ} 17^{\prime} 02.9^{\prime \prime} \mathrm{E}$, on calcareous rocks, 17.07.2015, leg. GU. Bujnaksk district, Talgi gorge, $42^{\circ} 52 ' 56.1^{\prime \prime} \mathrm{N}, 4^{\circ} 24^{\prime} 23.7^{\prime \prime} \mathrm{E}$, on calcareous rocks, 26.07.2015, leg. GU. This is the first report of the genus and species for Russia and Caucasus.

\#Protoparmelia montagnei (Fr.) Poelt \& Nimis Karabudakhkent district, $\mathrm{S}$ of Taulargol village, $42^{\circ} 49^{\prime} 36.5^{\prime \prime} \mathrm{N}, 47^{\circ} 35^{\prime} 05.6^{\prime \prime} \mathrm{E}$, on sandstone, 24.07.2015, leg. AI \& GU. Ibid., $2.5 \mathrm{~km} \mathrm{~S}$ of 


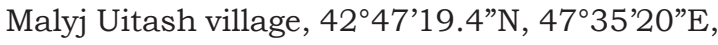
on sandstone, 24.07.2015, leg. AI \& GU. A mainly Mediterranean-Macaronesian species of siliceous rocks, abundant in arid and open sites (Barbero et al., 2006). This is the first convincing record of the species in Caucasus. The previous report of this thermophilous species from the subnival belt of the Kabardino-Balkaria Republic (Slonov, 2002) is doubtful.

RAMALINA CAPITATA (Ach.) Nyl. - Karabudakhkent district, S of Taulargol village, $42^{\circ} 49^{\prime} 36.5^{\prime \prime} \mathrm{N}$, $47^{\circ} 35^{\prime} 05.6$ " $\mathrm{E}$, on vertical and underhanging sandstone protected from rain, 24.07.2015, leg. AI \& GU. Ibid., Malyi Uitash village, $42^{\circ} 48^{\prime} 34.1^{\prime \prime} \mathrm{N}, 47^{\circ} 35^{\prime} 49.9^{\prime \prime} \mathrm{E}$, on vertical sandstone, 24.07.2015, leg. AI \& GU. Ibid., 2.5 $\mathrm{km} \mathrm{S}$ of Malyj Uitash village, $42^{\circ} 47^{\prime} 19.4^{\prime \prime} \mathrm{N}$, $47^{\circ} 35^{\prime} 20^{\prime \prime} \mathrm{E}$, on vertical and underhanging sandstone, 24.07.2015, leg. GU. The species is widely distributed in Caucasus: Krasnodar and Stavropol Areas, Republics of Northern Ossetia and Chechnya, Armenia, Azerbaijan and Georgia (Barkhalov, 1983).

RHIZOCARPON DISTINCTUM Th. Fr. - Karabudakhkent district, $\mathrm{N}$ of Taulargol village, $42^{\circ} 50^{\prime} 13^{\prime \prime} \mathrm{N}$, $47^{\circ} 34^{\prime} 58.5$ ” $\mathrm{E}$, on sandstone, 24.07.2015, leg. AI. In Caucasus, this species has been reported earlier from the Republics of Kabardino-Balkaria (Slonov, 2002), and from Armenia, Azerbaijan and Georgia (Barkhalov, 1983).

Rinodina CONFRAGOSA (Ach.) Körb. - Karabudakhkent district, $2.5 \mathrm{~km} \mathrm{~S}$ of Malyj Uitash village, 42 $47^{\prime} 19.4^{\prime \prime} \mathrm{N}, 47^{\circ} 35^{\prime} 20^{\prime \prime} \mathrm{E}$, on sandstone, 24.07.2015, leg. AI. In Caucasus, this species has been reported earlier from the Republics of Northern Ossetia (Vainio, 1899) and Adygea (Otte, 2007), from Armenia, Azerbaijan and Georgia (Barkhalov, 1983).

\#Strangospora deplanata (Almq.) Clauzade $\&$ Cl. Roux - Bujnaksk district, Talgi gorge, $42^{\circ} 52^{\prime} 56.1^{\prime \prime} \mathrm{N}, 4^{\circ} 24^{\prime 2} 23.7^{\prime \prime} \mathrm{E}$, on Acer campestre, 12.04.2013, leg. AI. New to Caucasus. This is the first report of the genus for the North-Caucasian lichen flora.

Thelenella muscorum (Fr.) Vain. - Karabudakhkent district, $2.5 \mathrm{~km} \mathrm{~S}$ of Malyj Uitash village, $42^{\circ} 47^{\prime} 19.4$ "N, $47^{\circ} 35^{\prime} 20^{\prime \prime} \mathrm{E}$, over the moss on sandstone, 24.07.2015, leg. GU. In Caucasus, this species has been reported earlier from the Republic of Kabardino-Balkaria (Vainio, 1899) and the Krasnodar Area (Krivorotov, 1997).
\#Tremella candelariellae Diederich \& Etayo - Karabudakhkent district, $2.5 \mathrm{~km} \mathrm{~S}$ of Malyj Uitash village, $42^{\circ} 47^{\prime} 19.4^{\prime \prime} \mathrm{N}, 47^{\circ} 35^{\prime} 20^{\prime \prime} \mathrm{E}$, lichenicolous fungus on thallus of Candelariella xanthostigma on Quercus petraea, 24.07.2015, leg. GU. New to Caucasus and Asia. It has been only once recorded from Russia before - in Murmansk region (Urbanavichus, 2016).

VerRUCARIA PRAERUPTA Anzi - Karabudakhkent district, the Caspian Sea shore, ca. 1.5 $\mathrm{km} \mathrm{S}$ of sanatorium "Chajka", 42 $41^{\prime} 08.7$ "N, $47^{\circ} 43^{\prime} 37.4$ "E, on calcareous rocks, 25.07.2015, leg. GU. New to Russia, Caucasus and Asia.

VeRRUCARIA SCHINDLERI Servít - Karabudakhkent district, the Caspian Sea shore, ca. 1.5 $\mathrm{km} \mathrm{S}$ of sanatorium "Chajka", 42 $41^{\prime} 08.7^{\prime} \mathrm{N}$, $47^{\circ} 43^{\prime} 37.4^{\prime \prime} \mathrm{E}$, on calcareous rocks, 25.07.2015, leg. GU. In Russia and Caucasus, this species has been recently reported from the Krasnodar Area (Urbanavichus \& Urbanavichene, 2015b).

\section{ACKNOWLEDGEMENTS}

We thank Dr Jan Vondrák for valuable suggestions and comments on the manuscript. We are also very grateful to Dr Volker Otte and anonymous reviewer for valuable suggestions and comments on the manuscript. This work was supported by a grant from the Russian Foundation for Basic Research (no. 15-29-02396).

\section{REFERENCES}

Barbero, M., Giralt, M., Elix, J. A., Gomez-Bolea, A. \& Llimona, X. 2006. A taxonomic study of Protoparmelia montagnei (syn. P. psarophana) centered in the Eastern Iberian Peninsula. Mycotaxon 97: 299-320.

Barkhalov, S. O. 1983. The Lichen Flora of the Caucasus. Baku. 183 pp. (In Russian).

Blinkova, O. \& Urbanavichus, G. 2005. Ecological analysis of lichens in the Teberda State Biosphere Reserve (North-Western Caucasus, Russia). Folia Cryptogamica Estonica 41: 23-35.

Breuss, O. 2009. A synopsis of the lichen genus Placopyrenium (Verrucariaceae), with descriptions of new taxa and a key to all species. Bibliotheca Lichenologica 99: 93-112.

Calatayud, V. \& Navarro-Rosinés, P. 2001. Bellemerella acarosporae and B. polysporinae (Verrucariales), two new species of lichenicolous fungi from Spain. Nova Hedwigia 72: 473-478. DOI:10.1127/nova. hedwigia/72/2001/473

Egea, J. M. \& Rowe, J. G. 1987. Lichenological excursion in North Africa. I. Silicicolous lichens 
in Morocco. Collectanea botanica [Barcelona] 17(1): 27-45. http://dx.doi.org/10.3989/collectbot.1988.v17.153

Gadjieva, Z. \& Solovyov, D. 1996. Climate. In: Akaev, B. A. et al. (ed.): Physical geography of Dagestan. Makhachkala, pp. 150-184. (In Russian).

Gasparyan, A. Aptroot, A., Burgaz, A. R., Otte, V., Zakeri, Z., Rico, V. J., Araujo, E., Crespo, A., Divakar, P. K. \& Lumbsch, H. T. 2015. First inventory of lichens and lichenicolous fungi in the Khosrov Forest State Reserve, Armenia. Flora Mediterranea 25: 105-114. http://147.163.105.223/ flora/25-105.pdf

Hafellner, J. 1995. A new checklist of lichens and lichenicolous fungi of insular Laurimacaronesia including a lichenological bibliography for the area. Fritschiana 5: 1-132.

Himelbrant, D. \& Kuznetsova, E. 2002. Lichens of the Subtropical Botanical Garden of Kuban' (Krasnodar region, Russian Caucasus). Botanica Lithuanica 8(2): 153-163.

Himelbrant, D. E., Kuznetsova, E. S. \& Konoreva L. A. 2003. Lichens of the Subtropical Botanical Garden of Kuban. In: Proceedings of XXII scientific conference of Botanical Gardens of the Northern Caucasus, dedicated to the 25th anniversary of the Subtropical Botanical Garden of Kuban. Sochi, pp. 22-25. (In Russian).

Ismailov, A. B. \& Urbanavichus, G. P. 2013. The first data on the lichen flora of Dagestan beech forests. Novitates Systematicae Plantarum Non Vascularum 47: 215-221. (In Russian, English summary). http://www.binran.ru/files/journals/ NSNR/2013_47/NSNR_2013_47_Ismailov_Urbanavichus.pdf

Krivorotov, S. B. 1997. Lichens and lichen communities of the North-Western Caucasus (Floristic and ecological analyses). Krasnodar. 201 pp. (In Russian).

Otte, V. 2005. Notes on the lichen flora of the Black Sea coast of Russia. Novitates Systematicae Plantarum Non Vascularum 39: 219-224. (In Russian). http://www.binran.ru/files/journals/ NSNR/2005_39/NSNR_2005_39_Otte.pdf

Otte, V. 2007. Flechten, lichenicole Pilze und Moose aus dem Nordwest-Kaukasus - zweiter Nachtrag. Herzogia 20: 221-237. http://www.blam-hp.eu/ Herzogia_20/H20-Otte_full.pdf

Otte, V., Esslinger, T. L. \& Litterski, B. 2002. Biogeographical research on European species of the lichen genus Physconia. Journal of Biogeography 29: 1125-1141. http://dx.doi.org/10.1046/ j.1365-2699.2002.00752.x

Ryan., B. D., Lumbsch, H. T., Messuti, M. I., Printzen, C., Sliwa, L. \& Nash, T. H. III. 2004. Lecanora. In: Nash, T. H. III, Ryan, B. D., Diederich, P., Gries, C., Bungartz, F. (Eds.): Lichen Flora of the Greater Sonoran Desert Region, Vol. 2. Lichens Unlimited, Arizona State University, Tempe, Arizona, pp. 176-286.

Slonov, T. L. 2002. The lichen flora of KabardinBalkaria and its analysis. Nalchik. 136 pp. (In Russian).

Urbanavichus, G. 2016. Additions to the lichens and lichenicolous fungi of Pasvik Reserve, Murmansk region, Russia. Graphis Scripta 28(1-2): 8-10. http://nhm2.uio.no/botanisk/lav/Graphis/28_1-2/GS_28_8.pdf

Urbanavichus, G. P., Gabibova, A. R. \& Ismailov, A. B. 2010. First records about lichenflora of Daghestan Reserve. Novitates Systematicae Plantarum Non Vascularum 44: 250-256. (In Russian, English summary). http:/ /www.binran.ru/files/journals/ NSNR/2010_44/NSNR_2010_44_Urbanavichus_et_al.pdf

Urbanavichus, G. \& Ismailov, A. 2013. The lichen flora of Gunib plateau in the Inner-mountain Daghestan (NE Caucasus, Russia). Turkish Journal of Botany 37: 753-768. http://journals.tubitak. gov.tr/botany/issues/bot-13-37-4/bot-37-4-171205-4.pdf

Urbanavichus, G. \& Urbanavichene, I. 2014. An inventory of the lichen flora of Lagonaki Highland (NW Caucasus, Russia). Herzogia 27(2): 285-319. http://dx.doi.org/10.13158/heia.27.2.2014.285

Urbanavichus, G. P. \& Urbanavichene, I. N. 2015a. A contribution to the lichen flora of Utrish Nature Reserve. Turczaninowia 18(2): 86-95. (In Russian, English summary). http://journal.asu.ru/index. php/tur/article/viewFile/798/474

Urbanavichus, G. \& Urbanavichene, I. 2015b. New records of lichens and lichenicolous fungi from the NW Caucasus (Russia). Herzogia 28: 185-192. http://dx.doi.org/10.13158/heia.28.1.2015.185

Vainio, E. A. 1899. Lichenes e Caucaso et in peninsula Taurica annis 1884-1885 ab H. Lojka et M. a Déchy collecti. Természetrajzi Füzetek 22: 269-343. 
70 Folia Cryptog. Estonica 